\title{
Studi Etnografi Virtual tentang Budaya Mahasiswa dalam Perkuliahan Online di Aplikasi Zoom
}

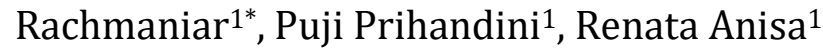 \\ ${ }^{1}$ Universitas Padjadjaran, Indonesia \\ *e-mail: rachmaniar@unpad.ac.id
}

Article history: Received 14 April 2021; Accepted 21 July 2021; Available online 31 August 2021

\begin{abstract}
Abstrak
Wabah coronavirus dimulai di kota Wuhan, Cina pada Desember dua tahun lalu. Dan hampir satu tahun para peserta didik dan pendidik melakukan pembelajaran online dari tempat nya masing-masing. Banyak pengalaman dan masalah yang terjadi dengan penggunaan aplikasi pembejaran yang digunakan. Dan ini tentu bisa dilihat melalui budaya virtual yang ada di dalamnya. Tujuan dari penelitian ini adalah untuk menganalisis budaya virtual dari perkuliahan online yang dilakukan mahasiswa bersama dosen dengan menggunakan aplikasi zoom, dilihat dari video, audio, dan fitur-fitur yang ada dalam aplikasi zoom. Metode yang digunakan untuk penelitian ini adalah metode kualitatif melalui pendekatan etnografi virtual untuk menganalisis budaya virtual mahasiswa dalam perkuliahan online di aplikasi zoom. Objek utama dalam penelitian ini adalah fitur-fitur yang ada dalam aplikasi zoom, seperti video, audio, virtual backgrounds, video filters, chat, dan reactions. Teknik pengumpulan data dilakukan melalui observasi partisipatif, wawancara, dan studi literatur. Teknik analisis data menggunakan analisis data model alur Miles dan Huberman. Sementara untuk teknik validitas data menggunkan member check. Hasil penelitian ini menunjukkan bahwa budaya virtual yang terbentuk atas penggunaan aplikasi zoom dalam perkuliahan online adalah: 1) video - banyak mahasiswa yang lebih memilih fitur mematikan kamera daripada menghidupkan kamera pada perkuliahan online; 2) audio - mahasiswa kerap mematikan fitur audio pada perkuliahan online; 3) virtual backgrounds - mahasiswa ada yang menggunakan fitur virtual backgrounds pada perkuliahan online; 4) video filters - mahasiswa ada yang menggunakan fitur video filters pada perkuliahan online; 5) chat - banyak mahasiswa yang memanfaatkan fitur chat pada perkuliahan online; dan 6) reactions - mahasiswa ada yang menggunakan fitur reactions pada perkuliahan online. Temuan dalam penelitian ini adalah pengajar harus memiliki sistem dan aturan yang dapat membuat proses belajar mengajar menjadi terarah dan berlangsung seperti yang diharapkan.
\end{abstract}

\footnotetext{
Abstract

The The coronavirus outbreak began in the Chinese city of Wuhan in December two years ago. Furthermore, for almost a year, students and educators do online learning from their respective places. Many experiences and problems occur with the use of the learning application used. Moreover, this can certainly be seen through the virtual culture that is in it. The purpose of this study is to analyze the virtual culture of online lectures conducted by students and lecturers by using the zoom application, seen from the video,
}

Kata Kunci:

Budaya Virtual;

Kuliah Online;

Aplikasi Zoom;

Etnografi Virtual

Keywords:

Virtual Culture;

Online Lectures;

Zoom Application;

Virtual Ethnography 
audio, and features in the zoom application. The method used for this research is a qualitative method through a virtual ethnographic approach to analyze the virtual culture of students in online lectures in the zoom application. The main object of this research is the features in the zoom application, such as video, audio, virtual backgrounds, video filters, chat, and reactions. The data collection technique was carried out through participatory observation, interview, and literature study. The data analysis technique uses data analysis of the Miles and Huberman flow model. Meanwhile, the data validity technique uses member checks. The results of this study indicate that the virtual culture formed by the use of the zoom application in online lectures is: 1) video - many students prefer to turn off the camera feature rather than turn on the camera in online lectures; 2) audio - students often turn off the audio feature in online lectures; 3) virtual backgrounds - some students use the virtual backgrounds feature in online lectures; 4) video filters - some students use the video filters feature in online lectures; 5) chat many students take advantage of the chat feature in online lectures, and 6) reactions - some students use the reactions to online lectures. The findings in this study are that teachers must have systems and rules that can make the teaching and learning process more focused and take place as expected.

Copyright @ Universitas Pendidikan Ganesha. All rights reserved.

\section{Pendahuluan}

Wabah coronavirus dimulai di kota Wuhan, Cina pada Desember dua tahun lalu. Bahaya potensial dari virus ini menjadi perhatian global ketika Dr. Li Wenliang dari sebuah rumah sakit di Wuhan berbagi pengetahuan yang dimilikinya dengan sesama dokter di WeChat terkait virus novel corona pada 30 Desember 2019. Kota itu mulai melaporkan kematian pada 22 Januari 2020. Dr. Li, yang pertama kali dituduh menyebarkan tipuan oleh polisi setempat, meninggal pada 7 Februari 2020 dalam usia 34 tahun. Ia kemudian dikonfirmasi telah terinfeksi seorang pasien virus corona yang berada di bawah pengawasannya.

Pada tanggal 11 Maret 2020, WHO menyatakan bahwa sekitar 70 persen dari 7,8 miliar populasi di dunia rentan terinfeksi oleh virus. Indonesia menjadi salah satu negara yang rentan dengan virus tersebut. Pemodelan oleh sekelompok ahli matematika pun dilakukan. Universitas Indonesia menyatakan bahwa puncak penularan di Indonesia saat itu akan terjadi pada 16 April 2020 dan kemudian secara bertahap menghilang antara Mei dan awal Juni 2020. Hal tersebut dapat terjadi jika langkah-langkah tertentu, seperti physical distancing dan berdiam diri di rumah dilakukan. Tanpa langkah-langkah mitigasi yang serius, puncak penularan saat itu akan berlanjut pada 4 Juni hingga September 2020.

Ahli lain menyatakan bahwa puncak penularan di Indonesia saat itu akan terjadi pada 2 Mei 2020 dengan asumsi bahwa langkah-langkah seperti physical distancing dan berdiam diri di rumah dilakukan oleh sebagian besar masyarakat Indonesia. Intinya adalah siklus virus dapat terputus karena adanya sikap publik.

Satuan Tugas Covid-19, Doni Monardo menyebut bahwa disiplin mengikuti himbauan pemerintah menjadi solusi terputusnya penyebaran virus corona. Kurangnya kerja sama dari publik akan membuat kebijakan apa pun menjadi tidak berguna, dan penyebaran virus pun terus berlangsung. Untuk itu pemerintah Indonesia terus menghimbau masyarakat agar ketat melakukan jarak fisik dan mengenakan masker wajah di mana pun mereka berada. Bahkan pada pertengahan Maret 2020, sejumlah daerah di Indonesia telah memutuskan untuk membatasi kegiatan publik, menutup sekolah, dan tujuan wisata sebagai bentuk memutuskan penyebaran virus corona 2019 (COVID-19). 
Banyak dari langkah-langkah ini bahkan datang sebelum pengumuman Presiden Joko "Jokowi" Widodo menghimbau masyarakat di seluruh pelosok nusantara untuk menjaga jarak satu sama lain dan bekerja serta belajar di rumah. Pemerintah Jakarta mengumumkan pada tanggal 14 Maret 2020 bahwa mereka akan menutup sekolah di seluruh kota dan menunda semua ujian selama dua minggu kedepan. Siswa di Jakarta akan belajar melalui pembelajaran jarak jauh. Hal ini dilakukan saat diketahui bahwa ada beberapa anak dinyatakan positif COVID19 , dan bisa menjadi pembawa virus serta menginfeksi orang dewasa.

Gubernur Jawa Tengah telah mengumumkan penutupan sementara semua sekolah di provinsi tersebut dan memerintahkan sekolah untuk menggunakan metode pembelajaran online selama 14 hari kedepan. Gubernur Jawa Barat Ridwan Kamil telah mengumumkan keputusan untuk menerapkan pembelajaran online selama dua minggu, mulai 16 Maret 2020. Dan ternyata pembelajaran online ini terus berlangsung hingga Maret 2021, hampir di seluruh wilayah Indonesia, baik di tingkat sekolah dasar maupun universitas, baik dengan peserta didik siswa dan mahasiswa, serta pendidik guru dan dosen.

Hampir satu tahun para peserta didik dan pendidik melakukan pembelajaran online dari tempat nya masing-masing. Semua dijalani dengan rasa suka cita dan menjadi pengalaman yang cukup berharga dalam proses pembelajarannya. Semua dilakukan dari rumah dan menggunakan banyak media dalam prosesnya. Salah satu media yang cukup popular dalam pembelajaran online adalah aplikasi zoom. Dalam kompas.com disebut bahwa aplikasi zoom menjadi aplikasi video conferencing yang banyak dipakai untuk sarana tatap muka, salah satunya adalah untuk kuliah online.

Selama satu tahun lebih penulis mengamati banyak hal menarik yang terjadi saat perkuliahan online berlangsung, baik dilihat dari video, audio, maupun fitur-fitur lain yang ada dalam aplikasi zoom. Atas hal tersebut, penulis menjadi tertarik untuk mengkaji berbagai budaya virtual yang hadir pada saat perkuliahan online di aplikasi zoom. Sehingga tujuan dari penelitian ini adalah untuk menganalisis budaya virtual dari perkuliahan online yang dilakukan mahasiswa bersama dosen dengan menggunakan aplikasi zoom, dilihat dari video, audio, dan fitur-fitur yang ada dalam aplikasi zoom. Guna menjawab keingintahuan penulis terkait budaya virtual dalam perkuliahan online dengan aplikasi zoom, penulis menggunakan pendekatan kualitatif dengan metode etnografi virtual.

\section{Metode}

Etnografi virtual adalah metode etnografi yang dilakukan untuk melihat fenomena sosial dan kultur pengguna di ruang siber (Nasrullah, 2014). Etnografi virtual mempertanyakan asumsi yang sudah berlaku secara umum tentang internet, menginterpretasikan sekaligus reinterpretasi internet sebagai sebuah cara sekaligus medium yang digunakan untuk berkomunikasi, merupakan "ethnography in, of and trough the virtual" - interaksi tatap muka atau face to face tidak diperlukan (Hine, 2001). Tom Boellstorff, professor di bidang antropologi University of California, US menyatakan bahwa penelitian etnografi virtual, pada dasarnya memiliki prinsip-prinsip yang sama dengan penelitian etnografi, dimana proses melakukan dan membangun etnografi menggunakan lingkungan virtual online sebagai lokasi penelitian. Boellstorf menyatakan bahwa pengumpulan data penelitian diluar lokasi (dunia virtual) penelitian sama saja dengan melanggar prinsip "in their own term", karena bagaimanapun juga segala sesuatu memiliki makna dalam konteksnya sendiri.

Dalam etnografi virtual, wawancara dan survei dapat digantikan oleh koleksi/arsip yang sudah ada yang berasal dari informasi yang melimpah di lingkungan online seperti situs jejaring sosial dan forum internet. Informasi dapat ditemukan dan diarsipkan dari internet tanpa harus dicatat dan ditulis seperti etnografer tradisional (Evans, 2010). Untuk itu etnografi virtual memberikan banyak kesempatan kepada peneliti untuk memilih objek virtual apa yang akan dikaji. Hal ini berarti bahwa sebuah penelitian yang menggunakan etnografi virtual, tidak selalu 
mengkaji materi-materi menyangkut isi tweet di timeline twitter, isi teks berita, atau penggambaran status seseorang di media sosial tertentu. Lebih jauh dari itu, hal-hal terkait audio, video, ataupun gambar meme sekalipun, jika hal tersebut hadir di dunia virtual, dapat dijadikan bahan untuk melihat budaya dari sekelompok orang yang ada dalam jagat maya (Rachman, 2017). Menggunakan metode etnografi virtual memungkinkan peneliti untuk melihat interaksi yang termediasi pada ranah virtual maupun fisik (Prajarto, 2018).

Etnografi virtual termasuk dalam metode penelitian kualitatif, dimana menggunakan beberapa sistem penyelidikan daripada prosedur logis dan statistic. Penelitian kualitatif berusaha melakukan proses penyelidikan naturalistik yang mencari pemahaman mendalam tentang fenomena sosial dalam pengaturan alaminya. Ini berfokus pada "mengapa" daripada "apa" dari fenomena sosial dan bergantung pada pengalaman langsung manusia sebagai agen pembuat makna dalam kehidupan sehari-hari mereka.

Penelitian kualitatif menawarkan pendekatan sistematis untuk mempelajari fenomena dalam konteks tertentu (Gast, 2010). Ini adalah eksplorasi dan upaya untuk mengembangkan penjelasan (Lincoln \& Guba, 1985). Fenomena diperiksa secara luas dan mendalam, yang sangat berguna ketika masalah berada pada tahap awal (Babbie, 1989). Data sering dihasilkan melalui wawancara, observasi langsung, hingga analisis artefak, dokumen dan catatan budaya, bahan visual atau pengalaman pribadi (Denzin \& Lincoln, 1994).

Berg dan Howard (2012) mencirikan penelitian kualitatif sebagai makna, konsep, definisi, metafora, simbol dan deskripsi hal-hal. Karenanya, pendekatan penelitian kualitatif menyediakan data berlimpah tentang orang-orang dan situasi kehidupan nyata (De Vaus, 2014; Leedy dan Ormrod, 2014). Ketergantungan pada pengumpulan data primer non-numerik seperti kata-kata dan gambar oleh peneliti yang berfungsi sebagai instrumen sendiri membuat penelitian kualitatif sangat cocok untuk memberikan fakta dan informasi deskriptif (Johnson dan Christensen, 2012). Bogdan dan Biklen (1982) menyatakan bahwa penelitian kualitatif adalah deskriptif yang datanya dikumpulkan dalam bentuk kata atau gambar daripada angka. Untuk itu prosedur dan tahapannya melalui hal-hal berikut, yaitu teknik pengumpulan data, teknik analisis data, dan teknik validitas data.

Dalam teknik pengumpulan data, penulis melakukan observasi selama satu tahun, lalu juga mewawancarai beberapa dosen dan mahasiswa terkait hal-hal yang ada dalam pembelajaran online menggunakan aplikasi zoom. Setelah itu penulis memperkaya data yang didapat dengan melakukan studi pustaka. Lalu untuk teknik analisis data, penulis melakukan reduksi data, penyajian data, dan penarikan kesimpulan. Setelah data-data diperoleh melalui obsevasi partisipastif selama satu tahun dan wawancara juga bersama narasumber, penulis kemudian menghubungkan data-data yang diperoleh, menganalisis nya, untuk selanjutnya mendapatkan kesimpulan tertentu. Dan untuk mengetahui bahwa kesimpulan yang didapatkan penulis sesuai serta tepat, penulis melalukan member check. yaitu suatu proses pengecekan data kepada sumber data, dengan tujuan agar informasi yang diperoleh dalam laporan penelitian memiliki kesesuaian dengan apa yang dimaksudkan oleh sumber data atau informan (Mekarisce, 2020).

\section{Hasil dan Pembahasan}

David Bell dalam buku Cyberculture Theorists menyebut bahwa budaya cyber atau budaya internet adalah suatu budaya yang muncul akibat adanya interaksi masyarakat dengan internet (Levy), sementara Bell menyebut bahwa budaya siber merupakan paradigma berpikir dan berintegrasi masyarakat dengan teknologi informasi.

Dalam budaya perkuliahan online yang akan ditelaah, ada hal-hal yang patut diketahui terkait penelitian mengenai perkuliahan online. Penelitian terdahulu yang menjadi rujukan adalah penelitian yang dilakukan oleh Mulyana, dkk. Dalam penelitian ini diketahui bahwa 
mahasiswa memberikan respon positif atas pelaksanaan perkuliahan daring ini dan bersedia selalu mengikutinya. Selanjutnya disebutkan pula bahwa penggunaan zoom direspon negatif oleh sebagian besar mahasiswa (Mulyana, dkk, 2020). Dan ini menjadi hal yang menarik untuk ditelaah, dikaitkan dengan budaya virtual yang mahasiswa lakukan selama perkuliahan online menggunakan aplikasi zoom.

\section{Fitur Video}

Dalam aplikasi zoom, diketahui ada fitur video, dengan pilihan start video (menghidupkan video atau menghidupkan kamera) dan stop video (mematikan video atau mematikan kamera). Fitur tersebut pada aplikasi zoom ada di bagian kiri bawah.

Para peserta bisa memilih start video, dalam artian hal-hal yang tertangkap oleh layar laptop atau smartphone dapat terlihat oleh peserta lain. Biasanya yang terlihat adalah wajah peserta dan latar belakang yang membingkainya. Aktivitas peserta sepanjang pertemuan di aplikasi zoom juga dapat dilihat peserta lain. Saat peserta tersebut melihat ke arah kamera, memegang smartphone, menguap, makan, berbicara dengan orang-orang yang ada di sekitranya, bahkan orang-orang yang berlalu lalang di belakang peserta pun dapat terlihat sepanjang orangorang tersebut tertangkap kamera laptop atau smartphone peserta.

Sementara jika para peserta memilih stop video, hal ini tentu sebaliknya. Hal-hal yang dilakukan peserta tidak akan diketahui peserta lainnya. Peserta seakan-akan bersembunyi di balik video atau kamera yang tertutup ini. Peserta tersebut sedang makan, sedang minum, sedang mendengarkan materi, atau sedang tidak berada di depan layar laptop atau smartphone, tidak akan diketahui peserta lainnya. Tampilan peserta di zoom biasanya bertuliskan nama peserta tersebut, atau pun nama peserta serta foto yang diunggah peserta dalam profile picture. Dan ternyata, berdasarkan pengamatan lebih dari satu tahun, stop video ini yang paling banyak dipilih peserta saat berada dalam perkuliahan online.

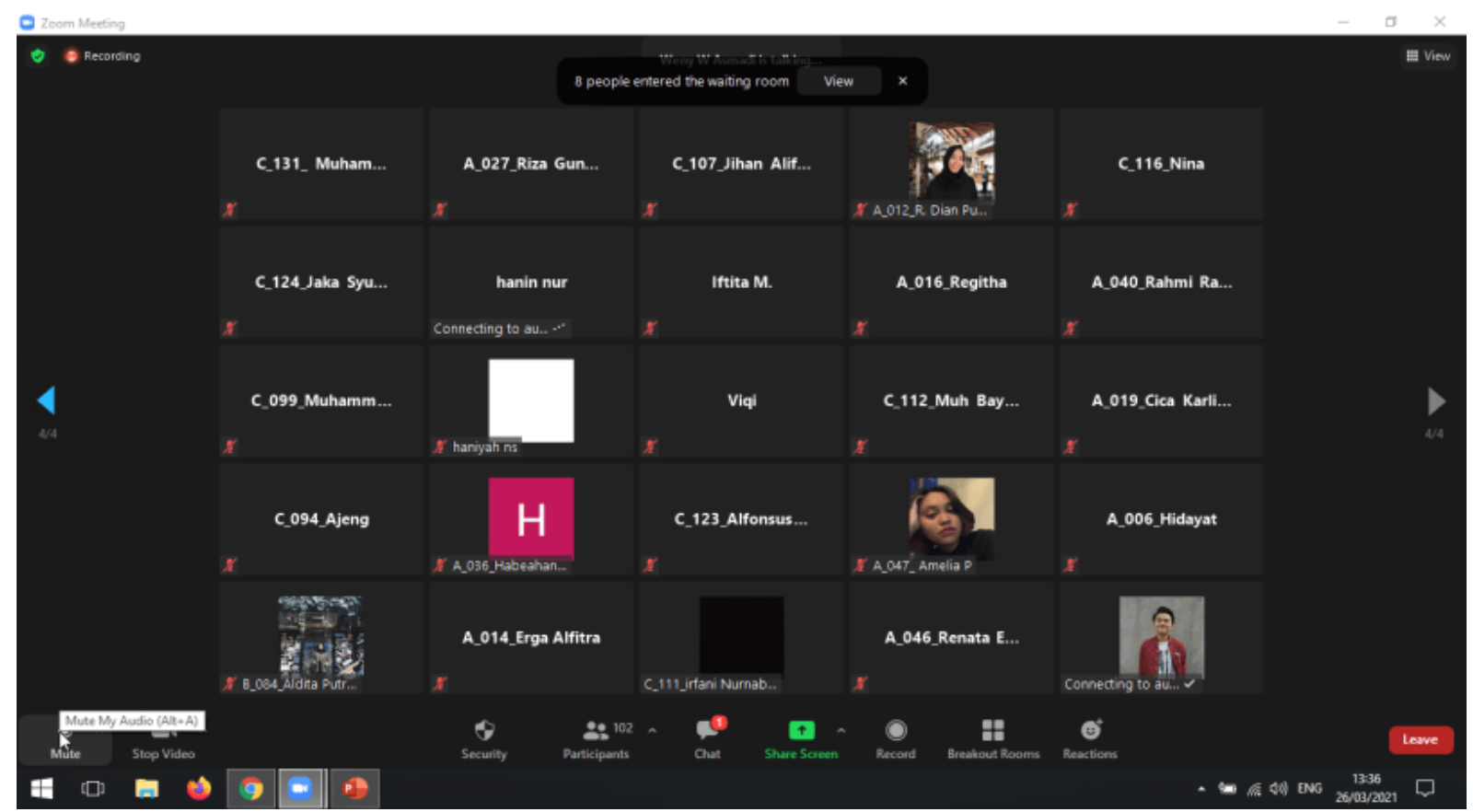

Gambar 1. Penggunaan video pada perkuliahan online

Para peserta biasanya menyampaikan permohonan maaf nya jika memilih stop video. Mereka mempunyai berbagai alasan atas pilihan tersebut - kamera laptop yang sedang bermasalah, situasi yang sedang tidak memungkinkan untuk menghidupkan kamera, ataupun sinyal yang sedang tidak bersahabat. Berbagai alasan disampaikan pada host atau tim pengajar. 
Dari hal tersebut, penulis menilai bahwa ada kenyamanan yang dirasakan peserta saat memilih stop video. Peserta tampak merasa bebas dengan aktivitasnya, tanpa diketahui peserta lain. Dalam The Johari Window Model, hal ini ada dalam hidden area - daerah tersembunyi, dimana hal-hal yang terjadi dengan peserta, hanya peserta tersebutlah yang mengetahuinya. Sementara peserta lain, termasuk host dan tim pengajar, tidak mengetahui hal-hal yang terjadi di balik video atau kamera yang tertutup ini. Dan hal ini jelas berbanding terbalik dengan area lain dalam The Johari Window Model, yaitu open area - daerah terbuka, dimana hal-hal yang terjadi dan dilakukan peserta saat itu, walau yang terlihat hanya seukuran layar laptop atau layar smartphone, peserta lain, host, serta tim pengajar dapat melihat dan menilai aktivitas.

Berdasarkan hal tersebut, penulis menilai bahwa faktor kebebasan menjadi hal yang mendominasi pilihan peserta untuk stop video. Peserta merasa aman tidak terlihat dalam layar laptop atau layar smartphone. Mereka merasa nyaman dengan pilihan mematikan kamera. Asumsi ini muncul karena saat tim pengajar meminta seluruh peserta untuk menghidupkan video atau menyalakan kamera saat perkulian online berlangsung, para peserta ternyata bisa melakukan hal tersebut tanpa ada kendala atau alasan-alasan yang sudah disebutkan sebelumnya. Terlebih jika tim pengajar menyebut bahwa para peserta yang stop video yang akan banyak diberi pertanyaan, karena video tidak terlihat, jadilah audio yang dijadikan sebagai bukti kehadiran saat itu. Serta merta para peserta menghidupkan kamera, dan jadilah mayoritas terlihat wajah dan aktivitasnya di perkuliahan online. Dan ini menjadi catatan tersendiri bagi tim pengajar agar mayoritas peserta membuka kamera. Hal ini menjadi penting agar peserta didik serius dan fokus dengan kegiatan belajar yang sedang dijalaninya. Meski pandemic, study from home tetap berlangsung sesuai dengan target dan goals yang diharapkan.

\section{Fitur Audio}

Sama hal nya dengan video, peserta pun dapat memilih fitur unmute my audio (menghidupkan suara) atau mute my audio (mematikan suara). Fitur tersebut pada aplikasi zoom ada di bagian kiri bawah. Ketika peserta memilih unmute my audio, tentunya semua suara yang ada di sekitaran peserta saat itu dapat terdengar oleh peserta lain, sepanjang peserta tidak mengalami gangguan sinyal atau audio dalam laptop atau smartphone nya tidak bermasalah. Dan sebaliknya, jika peserta memilih mute my audio, tentu semua suara yang ada di sekitaran peserta, termasuk suara peserta sendiri tidak dapat terdengar oleh peserta lain.

Berdasarkan pengamatan lebih dari satu tahun, para peserta sudah tertib dalam penggunaan fitur audio ini. Para peserta mengetahu waktu untuk menghidupkan suara dan mematikan suara. Saat mereka akan bertanya pada peserta lain, dalam hal ini peserta didik lain atau tim pengajar, mereka menghidupkan suaranya. Begitupun saat tim pengajar memberikan materi, dengan serta merta para peserta didik mematikan audionya. Sehingga proses belajar mengajar dapat berlangsung dengan baik. 


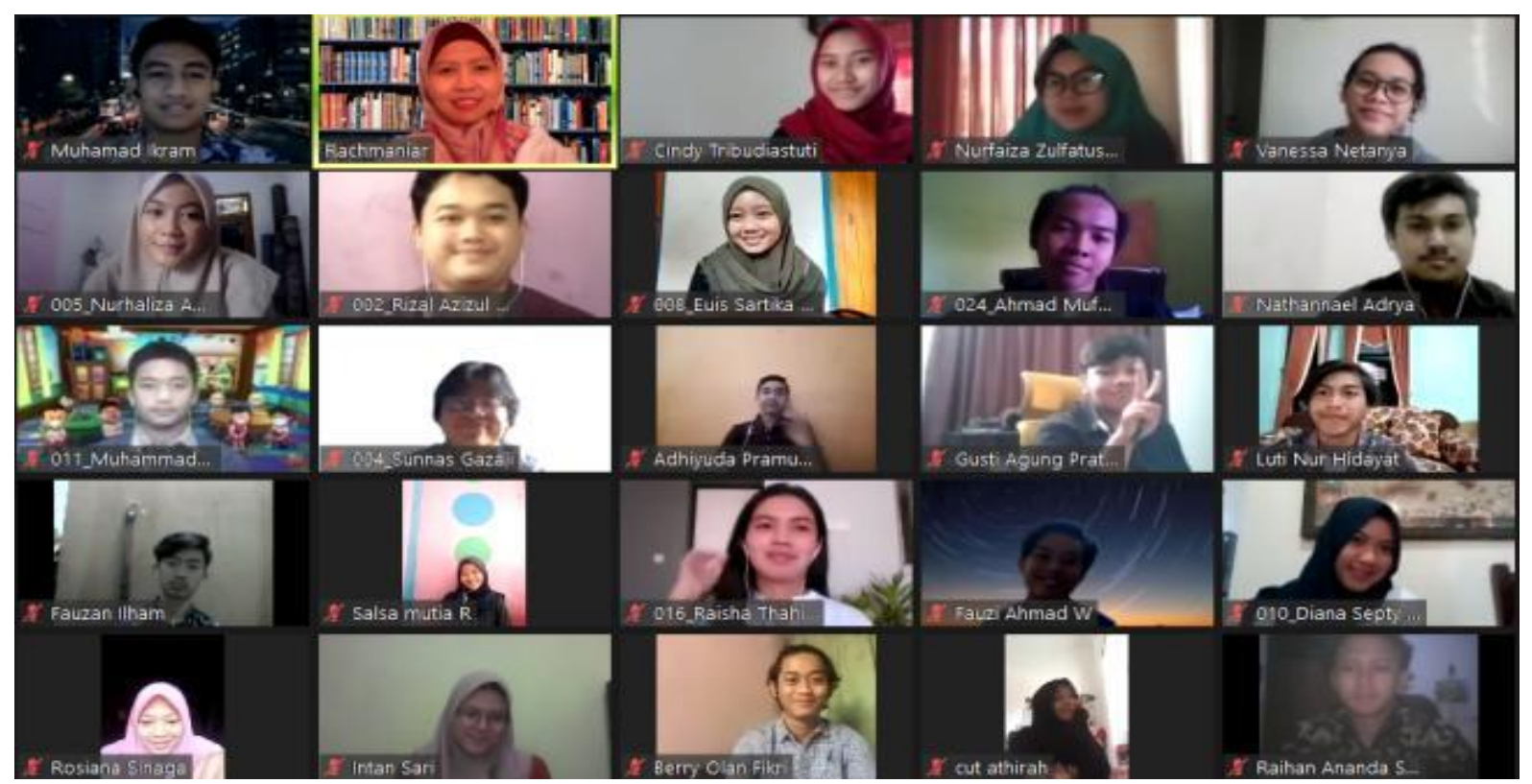

Gambar 2. Penggunaan audio pada perkuliahan online

Walau harus diakui bahwa kelupaan dalam mematikan suara pernah saja dialami oleh satu atau dua peserta saat perkuliahan online berlangsung. Para peserta ini masuk dalam zoom meeting, lalu mereka berbicara atau mendengarkan music, film tanpa mematikan suara di aplikasi zoom nya, jadilah suara-suara yang ada saat itu terdengar oleh seluruh peserta lain. Jika tim pengajar atau host tidak mematikan suara tersebut, bisa jadi suara dari peserta ini terus terdengar sepanjang perkuliahan online berlangsung.

\section{Fitur Virtual Background}

Virtual background adalah salah satu fitur yang terdapat dalam aplikasi zoom. Dalm fitur ini, peserta bisa memilih latar belakang apa yang ingin ditampilkan pada saat masuk zoom meeting. Mereka bisa memilih latar belakang pemandangan, rumah, tempat belajar, rak buku, dan lain-lain, sehingga saat mereka masuk dalam zoom meeting, lalu menghidupkan kamera, latar belakang yang dipilih tersebut akan tampak di layar zoom. Beberapa laptop atau smartphone sudah mendukung fitur tersebut, tetapi beberapa laptop atau smartphone lain, harus dibantu dengan green screen atau layar hijau untuk mendapatkan tampilan optimal. Jika tidak dibantu dengan green screen, biasanya wajah peserta bertumpuk dengan virtual background, dan menyebabkan tampilan peserta menjadi aneh di layar zoom.

Berdasarkan pengamatan lebih dari satu tahun, para peserta banyak yang tidak menggunakan fitur ini. Mereka cenderung menggunakan latar belakang tempat dimana mereka sedang melakukan aktivitas zoom saat itu. Para peserta banyak yang berada di rumahnya, di kamarnya, atau di ruang tertentu di dalam rumah. 


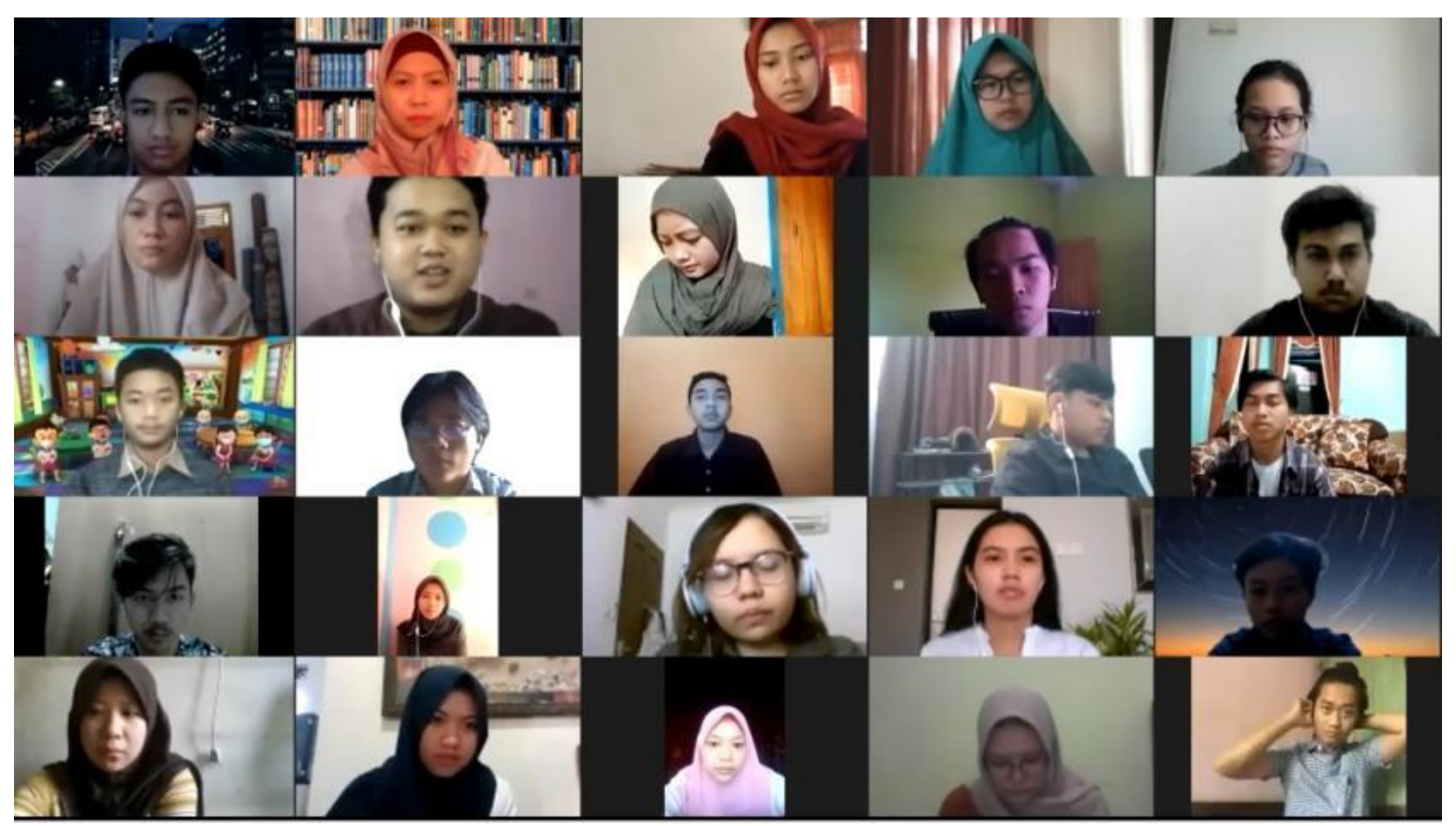

Gambar 3. Penggunaan virtual background pada perkuliahan online

Ada juga peserta yang berada di dalam kendaraannya, tempat makan, tempat job training, atau tempat lain yang tertutup. Jarang ada peserta yang menjadikan ruang terbuka sebagai tempat untuk melakukan aktivitas zoom meeting.

Lalu jika ada peserta yang memilih virtual background, mereka memiliki pilihan yang beragam. Di awal-awal pandemic, tepatnya di pertengahan Maret 2020, dimana saat itu mulai diberlakukannya perkuliahan online, banyak peserta yang memilih virtual background yang disediakan oleh zoom. Virtual background seperti pemandangan Jembatan San Francisco menjadi virtual background yang banyak dipilih. Lalu disusul dengan pemandangan ruang angkasa, dan juga rerumputan hijau.

Kemudian seiring dengan tingginya frekuensi penggunaan aplikasi zoom untuk perkuliahan online, beberapa peserta mulai variatif dalam pemilihan virtual background. Macam-macam virtual background hadir dalam perkuliahan online. Ada rak buku, kamar tidur yang nyaman, tempat belajar yang elegan, rumah yang mewah, atau foto-foto artis yang mereka sukai. Ada juga pemandangan pantai yang mempesona, dimana pemadangan tersebut memiliki efek-efek angin semilir yang menambah cantiknya virtual background yang ditampilkan. Pemandangan kota metropolitan, seperti New York, lalu juga ada beberapa acara televisi, ruang kelas, menambah semaraknya pemilihan virtual background yang digunakan peserta.

Poster kelompok, pemandangan kampus, hingga yang trend sekarang adalah dengan latar belakang blur, sehingga wajah peserta zoom menjadi tampak jelas dan focus menjadi salah satu virtual background yang juga beberapa kali hadir di ruang zoom meeting. Semuanya tampak menarik, dan menjadi pengalaman tersendiri bagi para peserta perkuliahan online.

\section{Fitur Video Filters}

Sama hal nya dengan virtual background, fitur ini bukan menjadi fitur yang kerap digunakan peserta zoom meeting. Fitur ini hadir dalam aplikasi zoom, dan peserta bisa memilih 
video filters apa yang mereka sukai. Disini peserta tidak bisa menambah video filters,mereka hanya bisa memilih dan menggunakan fitur ini saja. Hal ini sangat berbeda dengan virtual background, dimana peserta bisa menambah atau mengkoleksi virtual background yang mereka minati.

Lalu untuk menghadirkan fitur ini, peserta harus menghidupkan kamera. Peserta wajib memilih start video, lalu setelah itu masuk dalam video filters, kemudian memilih video filters apa yang ingin ditampilkan. Peserta yang memilih video filters tertentu, kadang-kadang tampilannya terlihat mencolok dan unik, dan ini acapkali mengundang tawa peserta zoom meeting yang lain.

Sementara untuk perkembangan dalam penggunaannya, di awal-awal pandemic, tepatnya di pertengahan Maret 2020, dimana saat itu mulai diberlakukannya perkuliahan online, banyak peserta yang tidak menggunakan video filters. Mereka tampak tidak familiar dengan fitur ini. Lalu seiring dengan tingginya frekuensi penggunaan aplikasi zoom, beberapa peserta mulai coba-coba menggunakan video filters, dan hal ini diikuti oleh peserta lainnya. Jadilah mereka mengenal fitur video filters .

Berdasarkan pengamatan lebih dari satu tahun, video filters yang kerap digunakan diantaranya adalah Noir dan Sepia. Kedua video filters ini kerap hadir pada saat perkuliahan online berlangsung santai dan serius. Noir dan Sepia juga menjadi video filters yang baru-baru ini dipilih, sebelumnya peserta didik menggunakan video filters, seperti Mosaic Eyewear, Analog Television, Happy Sprout, Halo, 6 Pixels Away, Face Mask, We can do it!, Graduation Cap, dan Beret, dimana peserta didik percaya diri menggunakan video filters ini manakala perkuliahan online berlansung santai.

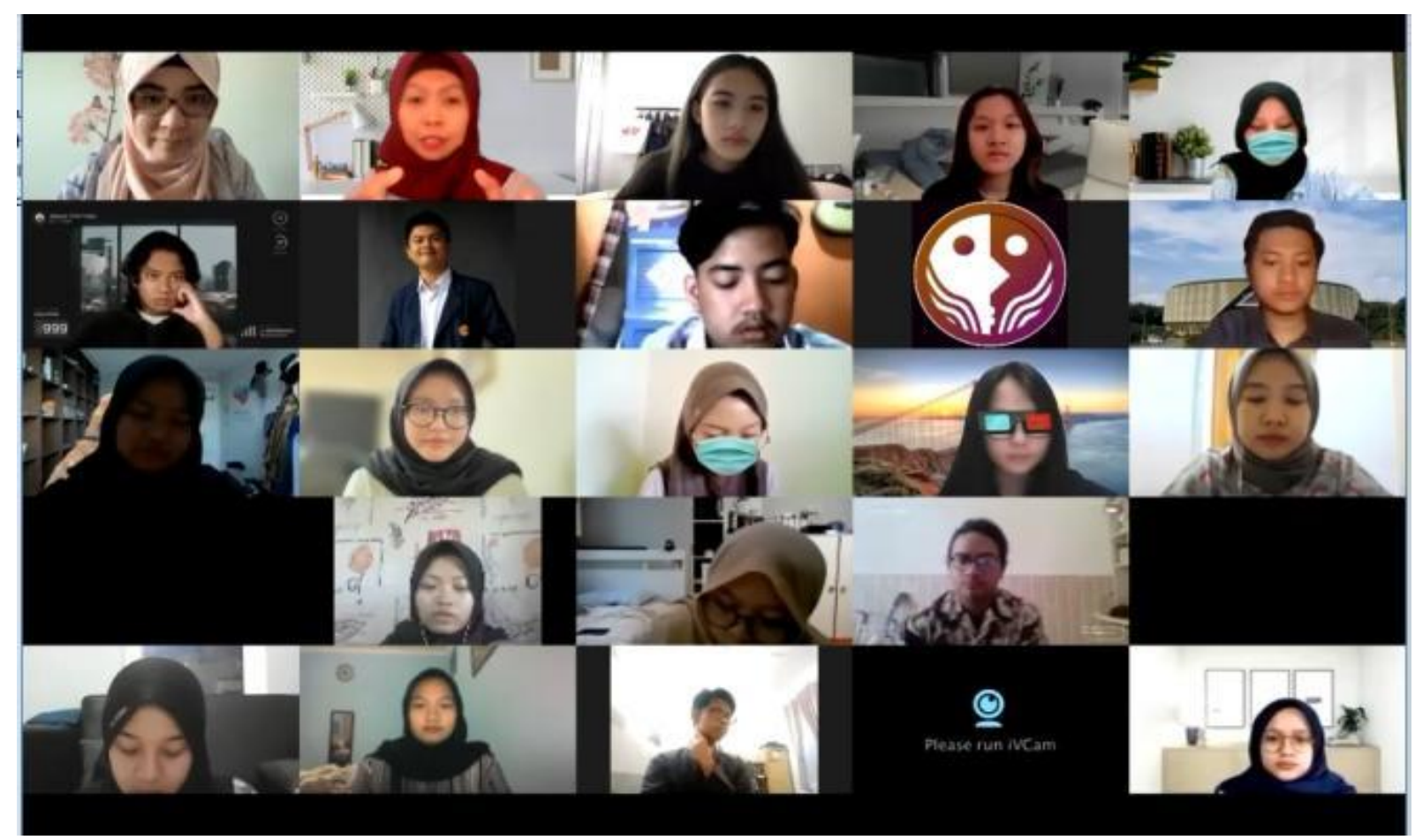

Gambar 4. Penggunaan video filters pada perkuliahan online

\section{Fitur Chat}

Berbeda dengan fitur-fitur yang ada dalam aplikasi zoom, fitur chat menjadi fitur yang sering digunakan peserta zoom meeting. Fitur ini posisinya berada di bagian tengah bawah, dengan cara penggunaan yang sangat mudah. Peserta cukup menuliskan sesuatu di fitur chat, 
lalu tekan enter, dan serta merta isi chat pun terkirim. Disini peserta bisa memilih, isi chat tersebut ditujukan untuk semua orang, atau peserta tertentu. Jika ditujukan untuk semua orang, isi chat akan terbaca oleh semua peserta zoom meeting. Tetapi jika isi chat ditujukan untuk peserta tertentu, hanya peserta tersebutlah yang bisa membaca isi chat.

Dalam fitur ini, semua peserta juga bisa mengirim file. Tetapi mengirim file lewat fitur chat yang ada dalam aplikasi zoom, sangat jarang dilakukan peserta. Hal ini berbeda dengan mengirim pesan teks. Berdasarkan pengamatan lebih dari satu tahun, mengirim pesan teks dalam fitur ini sudah mulai dimanfaatkan peserta di awal-awal pandemic. Saat mulai diberlakukan kuliah online, lalu tim pengajar juga mulai memanfaatkan aplikasi zoom, para peserta zoom tampak tidak ragu menggunakan fitur ini untuk mengirim teks. Mereka tampak familiar dalam penggunaannya. Terlebih saat sekarang ini, saat peserta terbiasa kuliah online dengan aplikasi zoom, pengiriman teks di kolom chat selalu terisi dengan chat peserta.

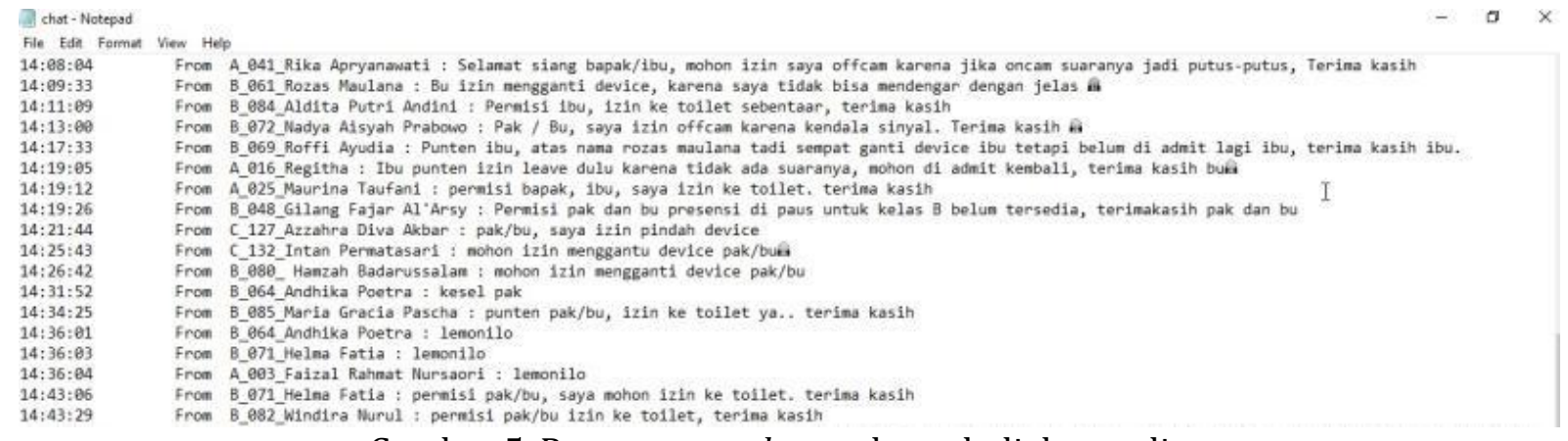
Gambar 5. Penggunaan chat pada perkuliahan online

\section{Fitur Reactions}

Sangat kontras dengan fitur chat, fitur ini jarang digunakan peserta di perkuliahan online. Terlebih di awal-awal pandemic, saat mulai diberlakukannya perkuliahan online, dimana peserta baru mengenal aplikasi zoom, fitur ini tidak ada yang menggunakan. Fitur yang posisinya berada di bagian kanan bawah ini, mulai ada yang menggunakan saat pertengahan pandemic. Dan hal ini berlaku hingga sekarang.

Berdasarkan pengamatan lebih dari satu tahun, fitur ini tidak selalu digunakan peserta zoom meeting di setiap perkuliahan online. Mereka menggunakan fitur ini ada yang atas kemauannya sendiri, ataupun saat tim pengampu meminta peserta memberikan reactions tertentu, baru beberapa peserta memunculkan reactions nya. Lalu untuk reactions yang kerap digunakan peserta zoom meeting adalah reactions raise hand, clap, thumbs up, dan heart. Untuk reaction raise hand, reactions ini sering digunakan peserta di pertengahan perkuliahan, saat tim pengampu menjelaskan materi tertentu, atau tim pengampu memberi kesempatan bertanya kepada peserta zoom meeting. Lalu untuk reactions clap, thumbs up, dan heart, kerap digunakan di akhir perkuliahan, sebagai respon peserta bahwa perkuliahan online menarik, seru, dan menyenangkan. Dan ini biasanya dilakukan peserta atas kemauannya sendiri, bukan karena permintaan dari tim pengampu. 


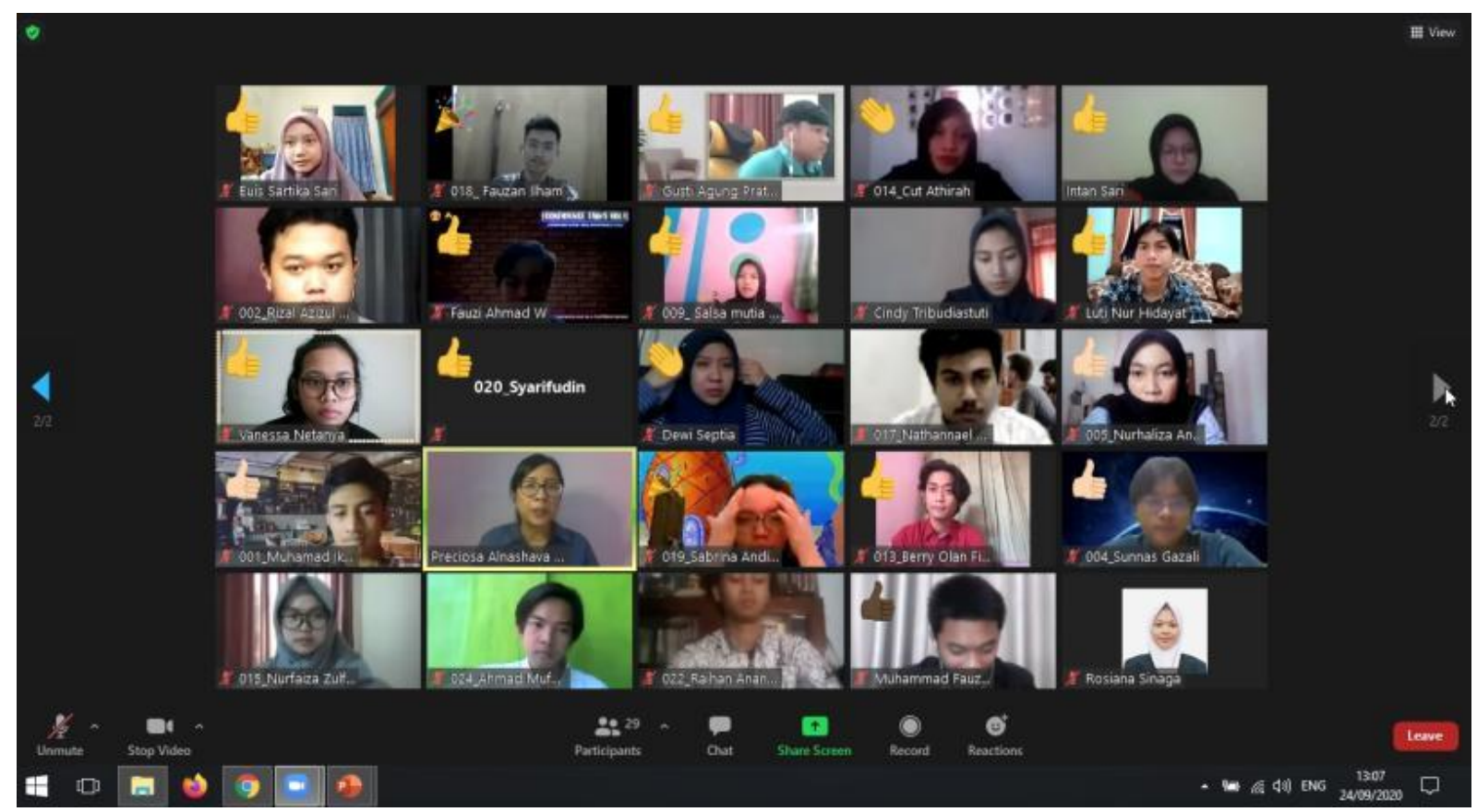

Gambar 6. Penggunaan reactions pada perkuliahan online

Temuan dalam penelitian ini adalah mahasiswa sebagai peserta zoom meeting lebih banyak yang memilih untuk tidak terlihat wajahnya saat perkuliahan online berlangsung, dimana hal tersebut sebenarnya menjadi sesuatu yang sangat disayangkan dalam proses belajar mengajar. Lalu untuk pengunaan audio, mahasiswa mayoritas tertib dalam penggunaannya, walau ada saja satu atau dua peserta yang lupa mematikan audio saat perkuliahan online berlangsung. Dan fiturfitur seperti, virtual backgrounds, video filters, dan reactions menjadi fitur-fitur yang jarang digunakan dalam perkuliahan online, kontras dengan fitur chat yang sering digunakan mahasiswa untuk mengirim pesan teks. Fitur chat menjadi fitur yang secara konsisten digunakan mahasiswa di setiap perkuliahan online.

\section{Simpulan dan Saran}

Berdasarkan pengamatan lebih dari satu tahun terkait perkuliahan online, diketahui bahwa mahasiswa memiliki budaya-budaya virtual terkait fitur-fitur yang ada dalam aplikas zoom. Budaya virtual pertama adalah banyak mahasiswa yang lebih memilih fitur mematikan kamera daripada menghidupkan kamera pada perkuliahan online di aplikasi zoom. Lalu untuk budaya virtual kedua adalah mahasiswa kerap mematikan fitur audio pada perkuliahan online di aplikasi zoom. Sementara untuk budaya virtual ketiga adalah mahasiswa ada yang menggunakan fitur virtual backgrounds pada perkuliahan online di aplikasi zoom. Kemudian untuk budaya virtual keempat adalah mahasiswa ada yang menggunakan fitur video filters pada perkuliahan online di aplikasi zoom. Selanjutnya untuk budaya virtual kelima adalah banyak mahasiswa yang memanfaatkan fitur chat pada perkuliahan online di aplikasi zoom. Terakhir untuk budaya virtual keenam adalah mahasiswa ada yang menggunakan fitur reactions pada perkuliahan online di aplikasi zoom. Untuk itu, rekomendasi yang bisa disampaikan dalam penelitian ini adalah pengajar harus memiliki sistem dan aturan yang dapat membuat proses belajar mengajar menjadi terarah dan berlangsung seperti yang diharapkan.

\section{Daftar Pustaka}

Babbie, E. (1989). The Practice of Social Research, 5th edition. Belmont CA: Wadsworth. Bell, D. (2007). Cyberculture Theories: Manuerl Castells and Donna Haraway. New York: Routledge. 
Berg, B. L. \& Howard, L. (2012). Qualitative Research Methods for the Social Sciences. (8th ed). USA: Pearson Educational Inc.

Boellstorff, T. (2008). Coming of Age in Second Life : An Anthropologist Explores The Virtually Human. New Jersey: Princenton University Press.

De Vaus, D. A. (2014). Surveys in Social Research. (6th ed). Australia: UCL Press.

Denzin, N.K. \& Lincoln, Y.S. (1994). Handbook of Qualitative Research. Thousand Oaks: Sage.

Gast, D. L. (2010). Single Subject Research Methodology in Behavioral Sciences. New York: Routledge.

Hine, C. (2001). Virtual Ethnography. London: Sage Publication Ltd.

Johnson, B. \& Christensen, L. (2012). Educational Research, Qualitative, Quantitative and Mixed Approach. (4th ed). California: SAGE Publication.

Leedy, P. \& Ormrod, J. E. (2014). Practical Research Planning and Design. (10th ed). Edinburgh: Pearson Educational Inc.

Lincoln, Y. S. \& Guba, E. G. (1985). Naturalistic Iinquiry. Beverly Hills, CA: Sage.

Mulyana,M., Rainanto, B.R., Astrini, D., \& Puspitasari, R. (2020). Persepsi Mahasiswa Atas Penggunaan Aplikasi Perkuliahan Daring Saat Wabah Covid-19. Jurnal Analisis Sistem Pendidikan Tinggi, 4(1).

Mekarisce, A.A. (2020). Teknik Pemeriksaan Keabsahan Data pada Penelitian Kualitatif di Bidang Kesehatan Masyarakat. Jurnal Ilmiah Kesehatan Masyarakat, 12(3).

Nasrullah, R. (2014). Teori dan Riset Media Siber (Cybermedia). Jakarta: Kencana.

Prajarto, N. (2018). Netizen dan Infotainment: Studi Etnografi Virtual pada Akun Instagram @lambe_turah. Jurnal Ilmu Komunikasi, 15(1).

Rachman, R. F. (2017). Menelaah Riuh Budaya Masyarakat di Dunia Maya. Jurnal Studi Komunikasi, 1(2). 